UDC 542.61

M.M. Cheltonov ${ }^{a}$, S.A. Oparin $^{b}$, A.S. Matrosov ${ }^{b}$, A.L. Kirichenko ${ }^{a}$

\title{
EXTRACTION OF HIGH-ENERGY COMPONENTS FROM PRODUCTS OF RECOVERY OF SOLID PROPELLANT USING DIMETHYL SULFOXIDE
}

\author{
${ }^{a}$ Pavlograd Chemical Plant, Pavlograd, Ukraine \\ ${ }^{b}$ Ukrainian State University of Chemical Technology, Dnipro, Ukraine
}

\begin{abstract}
The recycling of solid propellant from loaded rocket motor cases of intercontinental ballistic missiles SS-24 results in the formation of polymer crumb that is used as an energetic additive to emulsion explosives. The polymer crumb contains a binder, an oxidizer (ammonium perchlorate), energetic additives (nitramine, in particular cyclotetramethylenetetranitramine, and aluminium) and some additives. One of the most efficient techniques for utilization of polymer crumb consists in extraction of valuable high-energy components such as ammonium perchlorate and nitramine. To extract nitramine from solid propellant crumb, from which ammonium perchlorate has been previously removed, an organic solvent, dimethyl sulphoxide (DMSO), can be used. Nitramine is to be extracted from the obtained solid propellant polymer crumb by using DMSO. Then the extract is separated from the refined polymer crumb and nitramine is precipitated by the addition of water (a diluent that does not dissolve nitramine) to the extract solution. The purpose of this work was to establish the characteristics of the extraction process and determine the parameters of the extraction of nitramine from the products of solid propellant recycling (polymer crumb) with the use of DMSO. The effects of temperature, mechanical agitator rotation frequency and process duration on the degree of the extraction of nitramine from solid propellant polymer crumb by dimethyl sulfoxide were determined. The kinetic constants and the kinetic equation that describes the extraction of nitramine from solid propellant polymer crumb using DMSO were obtained. Ammonium perchlorate is present as a by-product in the spent DMSO aqueous solution. Ammonium perchlorate is a strong oxidizing agent and its presence is undesirable in the process of heating and regeneration of DMSO. Ammonium perchlorate can be removed from the spent DMSO aqueous solution by converting it into poorly soluble salt $\left(\mathrm{KClO}_{4}\right)$, which can be used as an oxidizing agent and in industrial explosives.
\end{abstract}

Keywords: solid propellant, extraction, cyclotetramethylenetetranitramine, ammonium perchlorate, dimethyl sulphoxide.

DOI: $10.32434 / 0321-4095-2020-129-2-141-147$

\section{Introduction}

Currently, Pavlograd Chemical Plant performs the disposal of loaded racket motor cases (LMCs) from SS-24 intercontinental ballistic missiles using a hydromechanical method. Solid propellant (SP) is a polybutadiene-based polymer binder, filled with an oxidizer (ammonium perchlorate), and containing energetic additives (cyclotetramethylenetetranitramine and aluminium) and some other process additives.

In the course of hydromechanical extraction and shredding of solid propellant with water, particles with the sizes ranging of $7 \times 4 \times 2 \mathrm{~mm}$ to $15 \times 4 \times 2 \mathrm{~mm}$ are formed, from which up to $40-50 \%$ of watersoluble oxidizing agent is extracted by leaching. Cyclotetramethylenetetraitramine (nitramine) can be extracted from the produced solid propellant polymer crumb with specific organic solvents, for example, dimethyl sulfoxide (DMSO) [1], followed by the separation of an extract and the precipitation of nitramine by the addition of water.

There is no technology for extracting nitramines from solid propellant in Ukraine. In this regard, it is necessary to study the extraction of nitramines from

(C) M.M. Cheltonov, S.A. Oparin, A.S. Matrosov, A.L. Kirichenko, 2020

Extraction of high-energy components from products of recovery of solid propellant using dimethyl sulfoxide 
SP, since the results of such research could be used in designing a pilot-industrial plant for the extraction of nitramine, a water-insoluble component of solid propellant.

The purpose of this work was to establish the characteristics of the extraction process and determine the main parameters for extracting nitramine from solid propellant disposal products, polymer crumb, with the use of DMSO.

\section{Experimental, results and discussion}

The effects of temperature, mechanical agitator rotation frequency and extraction process time on the degree of extraction of nitramine by dimethyl sulfoxide were determined in this work. Samples of shredded SP polymer crumb with particle sizes of $7 \times 4 \times 2 \mathrm{~mm}$ to $15 \times 4 \times 2 \mathrm{~mm}$ were used.

In the process of hydrodynamic destruction of missile bodies, a certain amount of ammonium perchlorate remains in polymer matrix (PM) of a solid propellant. This is undesirable because ammonium perchlorate is very soluble in DMSO and the subsequent heating during the regeneration of the extractant with a strong oxidizing agent $\left(\mathrm{NH}_{4} \mathrm{ClO}_{4}\right)$ would decompose DMSO to form dimethyl sulfone. In order to reduce the content of ammonium perchlorate, additional washing with water was performed at the temperature of $75-80^{\circ} \mathrm{C}$ for $2 \mathrm{~h}$ in a flask equipped with an agitator. As a result, the content of ammonium perchlorate in PM decreased from $28.1 \%$ to $8.8 \%$ (Table 1). Table 1 presents the full chemical composition of PM before and after washing with water.

Table 1

The chemical composition of PM before and after washing with water

\begin{tabular}{l|c|c}
\hline \multicolumn{1}{c|}{ Component } & $\begin{array}{c}\text { Content of } \\
\text { component } \\
\text { before washing } \\
\text { with water, \% }\end{array}$ & $\begin{array}{c}\text { Content of } \\
\text { component } \\
\text { after washing } \\
\text { with water, \% }\end{array}$ \\
\hline Polymer binder & 9.6 & 5.9 \\
\hline Ammonium perchlorate & 28.1 & 8.8 \\
\hline Nitramine & 29.5 & 24.4 \\
\hline Aluminium & 25.9 & 19.5 \\
\hline Moisture & 6.9 & 41.45 \\
\hline
\end{tabular}

The extraction of nitramine with DMSO from the polymer matrix after washing with water was carried out in a flask equipped with an agitator at a PM:DMSO ratio of $1: 2.5$. The parameters were changed as follows: the temperature of 20 to $80^{\circ} \mathrm{C}$, the mechanical agitator rotation frequency of 3.3 to $16.7 \mathrm{~s}^{-1}$, and the duration of extraction process of 1 to $4 \mathrm{~h}$. The following characteristics were taken as the basis ones: the temperature of $20^{\circ} \mathrm{C}$, the mechanical agitator rotation frequency of $6.7 \mathrm{~s}^{-1}$, and the duration of extraction process of $2 \mathrm{~h}$. When changing one of the parameters, the other parameters remained constant.

The refined PM suspension was filtered, dried and weighed.

At the next stage, the mother liquor was put into a flask. At stirring, water (a diluent) was added to adjust a DMSO:water ratio of 1:1. Then, a formed polydisperse precipitate of nitramine was filtered, dried and weighed. The degree of extraction was determined by the ratio of the actual weight to the theoretically extractable weight of nitramine. Infrared spectra were recorded using a Spekord 75-UR spectrometer ( $\mathrm{KBr}$ pellets) for extracted nitramine and commercial grade nitramine.

During the process of nitramine extraction, a certain amount (up to 3\%) of ammonium perchlorate is transferred into DMSO. In order to reduce the concentration of $\mathrm{NH}_{4} \mathrm{ClO}_{4}$, an equivalent amount of $\mathrm{KOH}$ was added to the spent DMSO solution. To this end, an equivalent amount of $\mathrm{KOH}$ in the form of saturated aqueous solution was added to the flask equipped with an agitator in which the obtained DMSO aqueous solution is present. Thus, $\mathrm{ClO}_{4}^{-}$ ion is fixed as a poorly soluble salt $\left(\mathrm{KClO}_{4}\right)$. The solution was cooled to $-16^{\circ} \mathrm{C}$, and the obtained $\mathrm{KClO}_{4}$ was filtered, dried and weighed. The yield was determined by the ratio of the weight of extracted potassium perchlorate to the theoretically obtained weight, and the thermal stability was estimated by the differential thermal analysis (DTA).

Based on the results of the research conducted, the dependences of the degree of nitramine extraction on the temperature, time of extraction process and agitator rotation frequency were obtained (Figs. 1$3)$.

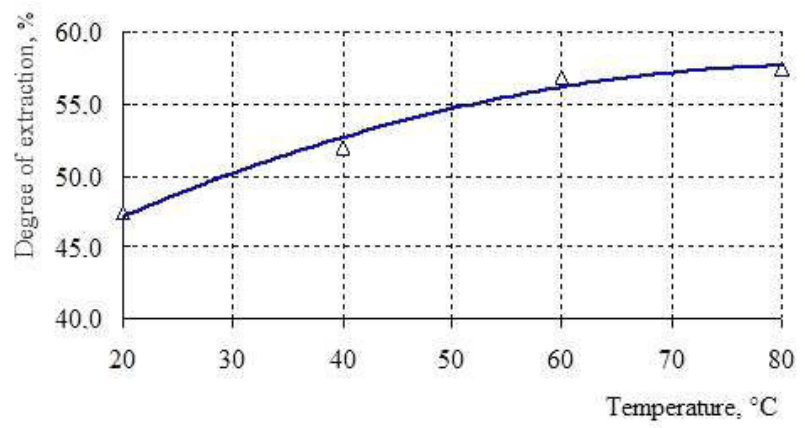

Fig. 1. The dependence of the degree of nitramine extraction on the temperature at the mechanical agitator rotation frequency of $6.7 \mathrm{~s}^{-1}$ and the time of extraction process of $2 \mathrm{~h}$ 


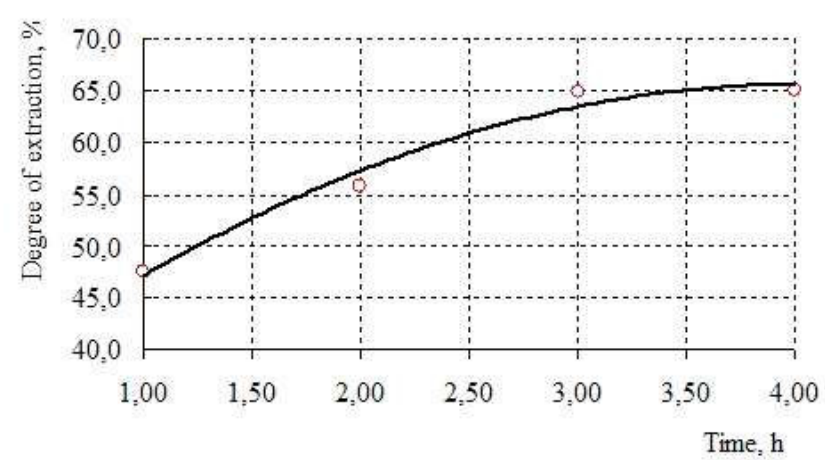

Fig. 2. The dependence of the degree of nitramine extraction on the time of extraction process at the temperature of $20^{\circ} \mathrm{C}$ and the mechanical agitator rotation frequency of $6.7 \mathrm{~s}^{-1}$

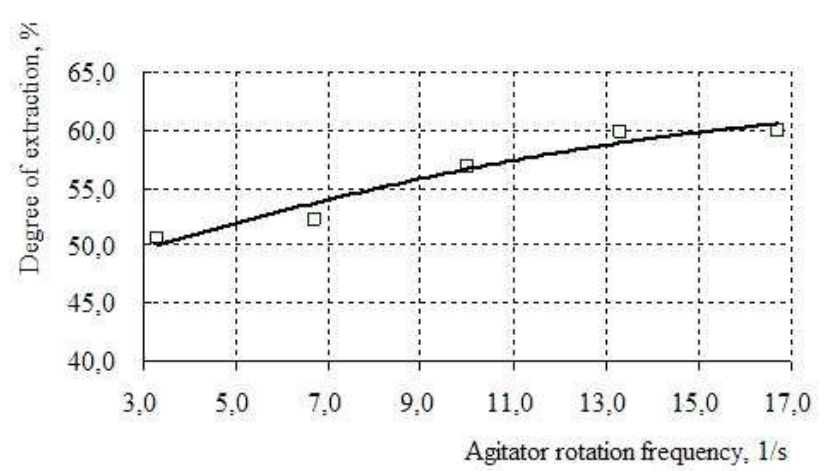

Fig. 3. The dependence of the degree of nitramine extraction on the agitator rotation frequency at the temperature of $20^{\circ} \mathrm{C}$ and the time of extraction process of $2 \mathrm{~h}$

The dependences plotted in Figs. 1-3 show that the degree of nitramine extraction increases according to polynomial dependences with an increase in extraction temperature, agitator rotation frequency and duration of extraction process. The obtained dependences are well described by the following approximating equation (the $\mathrm{R}$-squared value $R^{2} \geq 0.95$ ):

$\eta=\alpha x^{2}+\beta x+c$,

where $\eta$ is the degree of nitramine extraction (\%); $\mathrm{a}, \mathrm{b}$, and $\mathrm{c}$ are the empirical coefficients depending on the extraction temperature $(a=-0.0025, b=0.425$, and $\mathrm{c}=39.65$ ), the duration of extraction process $(a=-2, b=16.16$, and $c=32.95)$, and the agitator rotation frequency $(a=-0.03, b=1.3845$, and $\mathrm{c}=45.748$ ).

Dimethyl sulfoxide, as an extractant of nitramine from polymer crumb of composite solid propellant, allows extracting the target product with an extraction degree of up to $65.1 \%$ if the extraction is performed at the following parameters: duration of $4 \mathrm{~h}$, temperature of $20^{\circ} \mathrm{C}$, and mechanical agitator rotation frequency of $6.7 \mathrm{~s}^{-1}$.

As follows from Fig. 1, the optimum temperature for the extraction of nitramine from PM under the given conditions is equal to ca. $60-80^{\circ} \mathrm{C}$, thereby yielding the extraction degree of 56.9-57.4\%.

Analysis of the data given in Fig. 2 shows that the optimum extraction time is 2 to 4 hours, the degree of nitramine extraction in this case being 55.8$65.1 \%$.

Finally, the data of Fig. 3 indicate that the optimum mechanical agitator rotation frequency when extracting nitramine from PM under the given conditions is in the range of 13.3 to $16.7 \mathrm{~s}^{-1}$, the extraction degree being 59.8-60.0\%.

In order to determine the effect of the duration of the extraction of nitramine from PM, the change in the concentration of nitramine in DMSO solution with time at the temperature of $20^{\circ} \mathrm{C}$ and the mechanical agitator rotation frequency of $6.7 \mathrm{~s}^{-1}$ was considered. Table 2 shows the values of the kinetic parameters of the nitramine extraction from PM.

The values of kinetic parameters of the process of Table 2 nitramine extraction from PM

\begin{tabular}{c|c|c}
\hline $\mathrm{t}, \mathrm{s}$ & $\mathrm{C}, \mathrm{kg} / \mathrm{m}^{3}$ & $\ln \left(1-\left(\mathrm{C} / \mathrm{C}_{\mathrm{p}}\right)\right)$ \\
\hline 3600 & 51.08 & -1.31 \\
\hline 5400 & 55.59 & -1.58 \\
\hline 7200 & 59.88 & -1.94 \\
\hline 9000 & 64.90 & -2.64 \\
\hline 10800 & 69.69 & -3.09 \\
\hline 12600 & 69.72 & -3.75 \\
\hline 14400 & 69.87 & - \\
\hline
\end{tabular}

The obtained values given in Table 2 well obey a curve that is described by the following equation (a pseudo-first-order reaction) [2-4]:

$\mathrm{C}=\mathrm{C}_{\mathrm{p}}\left(1-\mathrm{Ae}^{-\mathrm{kt}}\right)$,

where $\mathrm{C}$ is the current concentration of nitramine in the solution $\left(\mathrm{kg} / \mathrm{m}^{3}\right) ; \mathrm{C}_{\mathrm{p}}$ is the equilibrium concentration of nitramine in the solution $\left(\mathrm{kg} / \mathrm{m}^{3}\right)$; $\mathrm{A}$ is the pre-exponential factor; $\mathrm{k}$ is the mass transfer coefficient $\left(\mathrm{s}^{-1}\right)$; and $\mathrm{t}$ is time (s).

It should be noted that the value of $\mathrm{C}_{\mathrm{p}}$ is $69.87 \mathrm{~kg} / \mathrm{m}^{3}$ [2-4].

Equation (2) in the logarithmic form takes the following form:

$\ln \left(1-C / C_{p}\right)=\ln A-k t$. 


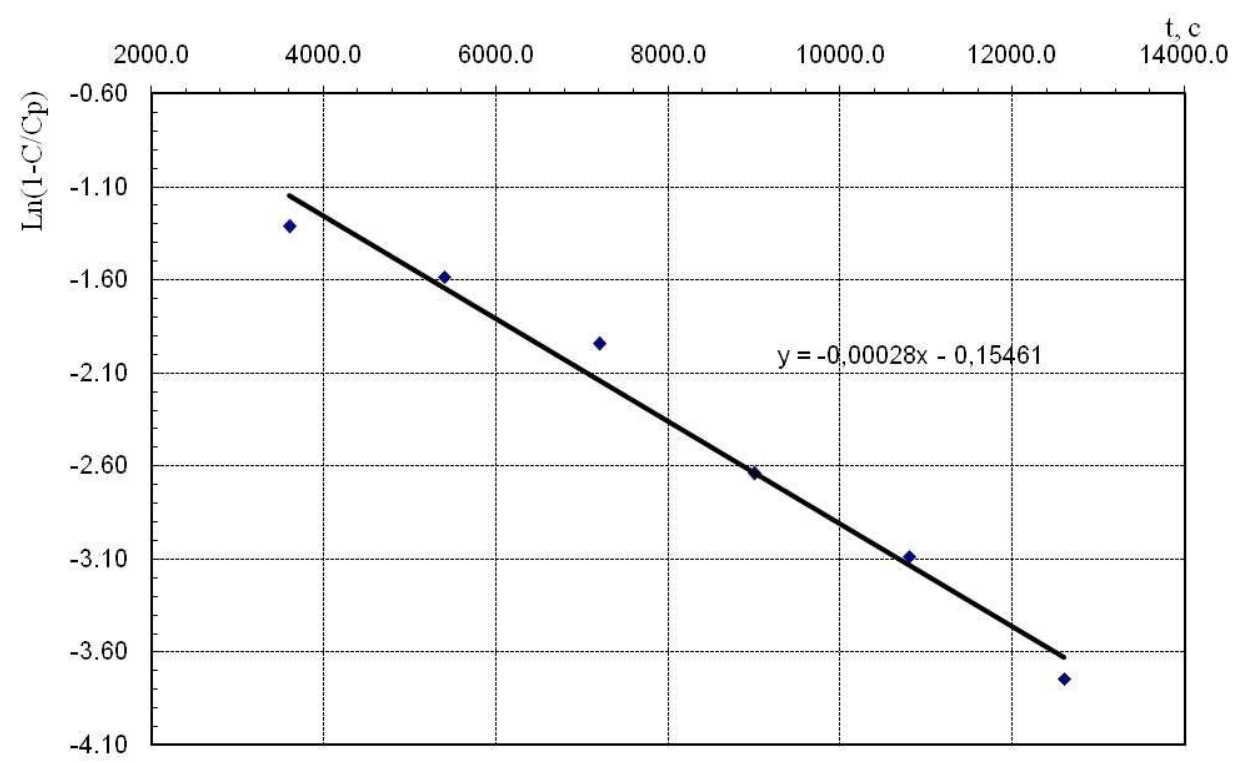

Fig. 4. The kinetic dependence of nitramine extraction from PM

It is clear that the slopes and intersections of the straight lines plotted in coordinates $\ln \left(1-\mathrm{C} / \mathrm{C}_{\mathrm{p}}\right)$ vs. $\mathrm{t}$ allow determining the values of $\mathrm{A}$ and $\mathrm{k}$.

Figure 4 shows the kinetic dependence of nitramine extraction from PM plotted according to Eq. (3). Here the R-squared value is $R^{2}=0.98$.

The kinetic constants and the kinetic equation for nitramine extraction from PM are shown in Table 3.
Table 3

The kinetic constants and the general kinetic equation for nitramine extraction from PM

\begin{tabular}{c|c}
\hline $\mathrm{k}$ & $2.8 \cdot 10^{-4}$ \\
\hline $\ln \mathrm{A}$ & -0.155 \\
\hline $\mathrm{A}$ & 0.857 \\
\hline Kinetic equation & $\mathrm{C}=69.87 \cdot\left(1-0.857 \cdot \exp \left(-2.8 \cdot 10^{-4} \mathrm{t}\right)\right)$ \\
\hline
\end{tabular}

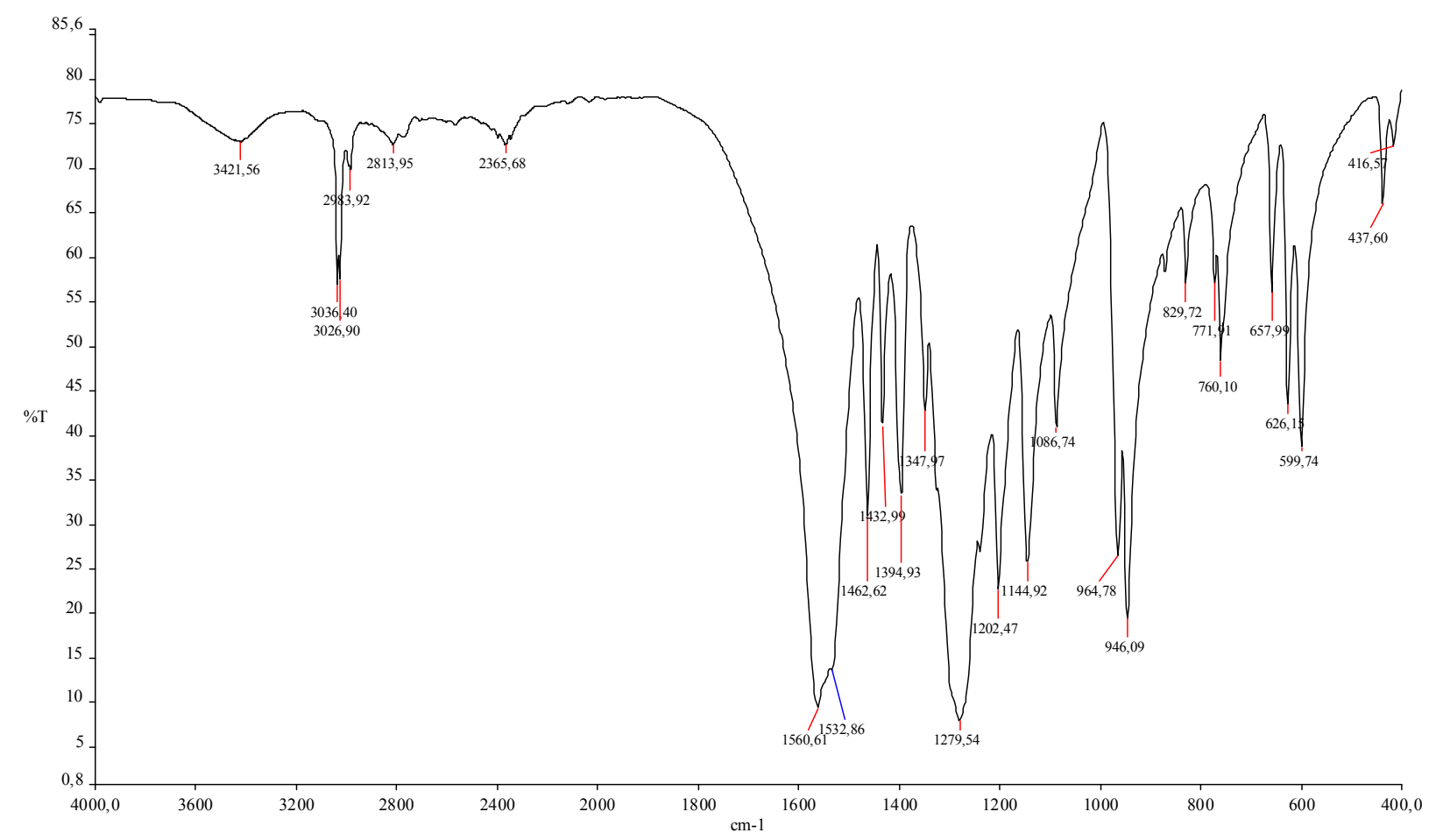

Fig. 5. The IR spectrum of the obtained nitramine 


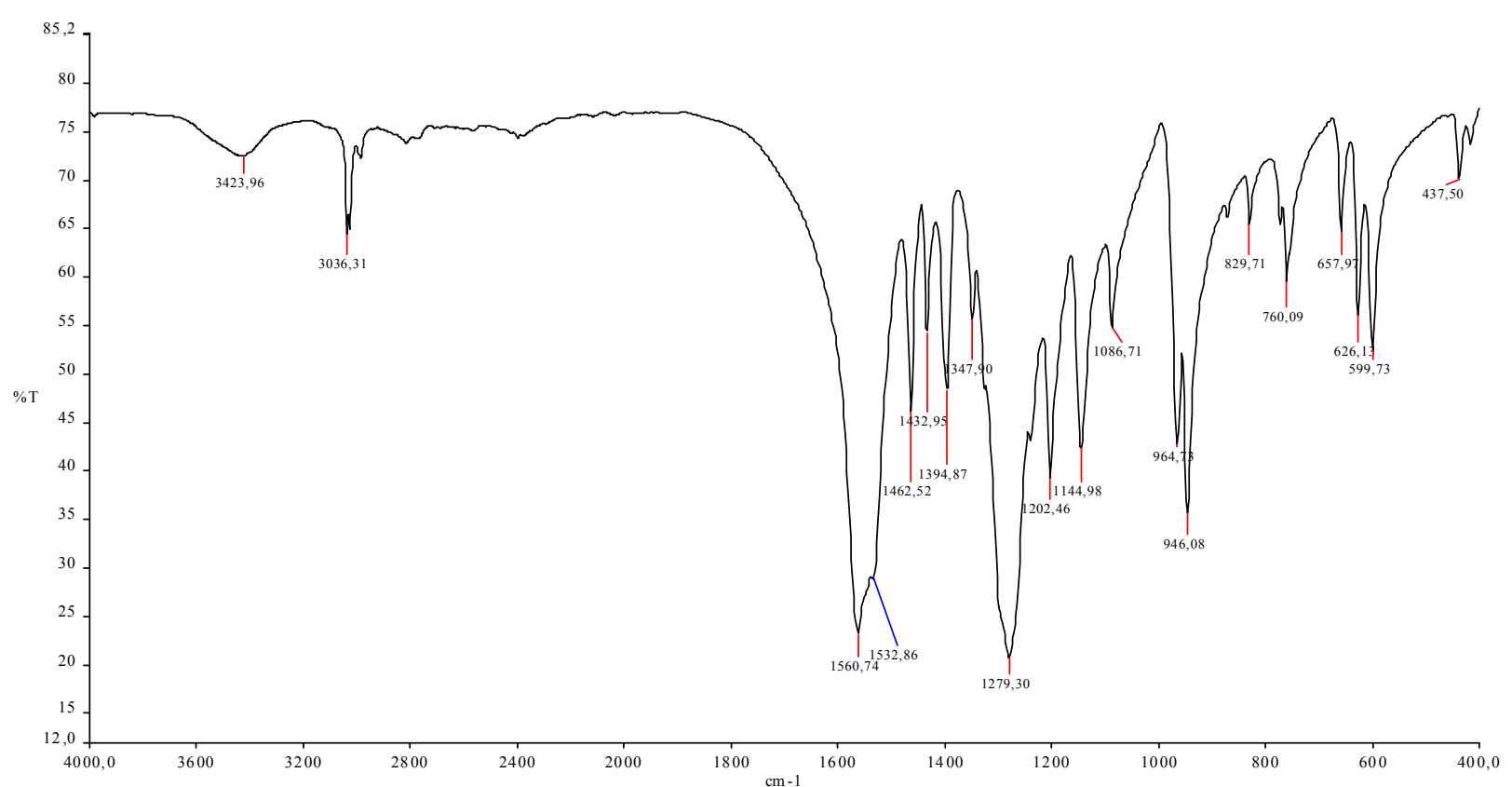

Fig. 6. The IR spectrum of commercial nitramine

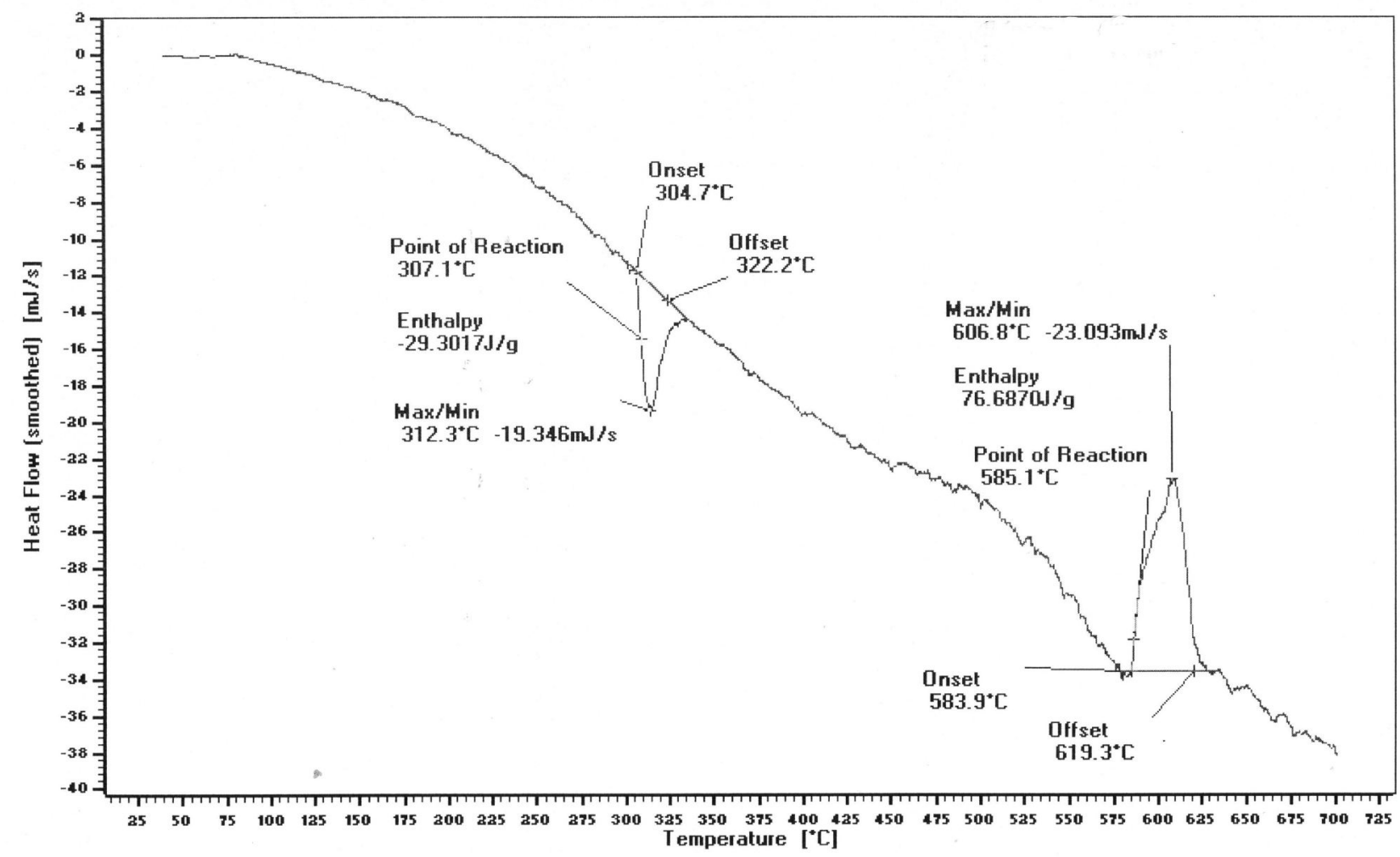

Fig. 7. The DTA thermogram of the obtained potassium perchlorate (heating rate of $10^{\circ} \mathrm{C} / \mathrm{min}$ )

The recorded infrared spectra of nitramine extracted from PM using DMSO and commercial grade nitramine (Figs. 5 and 6) show similar absorption bands at $1560,1280,946$, and $760 \mathrm{~cm}^{-1}$ that can be attributed to the presence of the $\mathrm{N}-\mathrm{NO}_{2}$ group.
Extracted nitramine after its modification can be reused in compositions of heat-resistant explosives, solid propellant and non-electric initiation systems.

The method described above was used to obtain $\mathrm{KClO}_{4}$ with a yield of $68 \%$ with respect to the theoretical yield, and the DTA-curve of the obtained 
potassium perchlorate (at the heating rate of $10^{\circ} \mathrm{C} / \mathrm{min}$ ) is shown in Fig. 7. According to the results of DTA-analysis, an endothermic peak in the temperature range of $304.7-322.2^{\circ} \mathrm{C}$ corresponds to the transition modification of potassium perchlorate [5]. A second endothermic peak appears in the range of $545-585^{\circ} \mathrm{C}$, corresponding to the melting of potassium perchlorate with its subsequent decomposition, as evidenced by the pronounced exothermic peak in the temperature range of 583.9$619.3^{\circ} \mathrm{C}$.

The extracted $\mathrm{KClO}_{4}$ by-product can be reused as an oxidizing agent in solid propellants and industrial explosives. Refined PM can be further used as a filler in compositions of emulsion explosives.

\section{Conclusions}

The effects of temperature, mechanical agitator rotation frequency and duration of process on the degree of extraction of nitramine obtained in the extraction from PM by using dimethyl sulfoxide were determined in this work.

It was found that the highest degree of extraction $(65.1 \%)$ in terms of the target product during the extraction with DMSO from PM was achieved in the experiment that lasted for 4 hours at the temperature of $20^{\circ} \mathrm{C}$ and the mechanical agitator rotation frequency of $6.7 \mathrm{~s}^{-1}$.

The optimum parameters for nitramine extraction from PM using DMSO were established as follows: the temperature of $60-80^{\circ} \mathrm{C}$, the extraction duration of 2-4 hours and the mechanical agitator rotation frequency of $13.3-16.7 \mathrm{~s}^{-1}$.

Kinetic constants and kinetic equation for the process of extracting nitramine from PM using DMSO were obtained. A linear graph in logarithmic coordinates was plotted to describe the kinetics of nitramine extraction from PM with the R-squared value of $\mathrm{R}^{2}=0.98$.

The extracted product was identified as nitramine using the IR-spectroscopy method.

\section{REFERENCES}

1. Kim K.J., Kim H.S., Sim J.S. Solubilities of octahydro1,3,5,7-tetranitro-1,3,5,7-tetrazocine in $\gamma$-butyrolactone + water, dimethylsulfoxide + water, and N-methyl pyrrolidone + water // J. Chem. Eng. Data. - 2013. - Vol.58. - P.2410-2413.

2. Dyachok $V$. Extraction process of intracellular substance // Chem. Chem. Technol. - 2010. - Vol.4. - No. 2. - P.163166.
3. Dyachok V., Maljovanyj M., Ilkiv I. Some kinetic regularities of intracellular substance extracting // Chem. Chem. Technol. - 2011. - Vol.5. - No. 4. - P.469-472.

4. Dyachok V., Ilkiv I. On the mechanism of extraction from solid bodies cellular structure // Chem. Chem. Technol. 2013. - Vol.7. - No. 1. - P.23-27.

5. Влияние катализаторов на термическое разложение перхлората калия и взрывчатые характеристики составов на его основе / Закусило В.Р., Романченко А.М., Закусило Р.В. // Вісник Кременчуцького держ. ун-ту ім. М. Остроградського, 2013. - Вип. 5/2013 (82). - С.103-107.

Received 22.10.2019

\section{ЕКСТРАКЦІЯ ВИСОКОЕНЕРГЕТИЧНИХ КОМПОНЕНТІВ 3 ПРОДУКТІВ УТИЛІЗАЦІЇ ТВЕРДОГО РАКЕТНОГО ПАЛИВА ІЗ ЗАСТОСУВАННЯМ ДИМЕТИЛСУЛЬФОКСИДУ}

\section{М.M. Челтонов, С.O. Опарін, О.С. Матросов, О.Л. Кириченко}

У процесі утилізації твердого ракетного палива зі споряджених корпусів двигунів утворюється полімерна крихта, яка знайшла застосування в якості енергетичної добавки в складі емульсійних вибухових речовин. До складу полімерної крихти входить: сполучна, окислювач (перхлорат амонію), енергетичні добавки (нітраміни, зокрема ціклотетраметілентетранітрамін, алюміній) і технологічні добавки. Одним зі способів використання полімерної крихти є одержання цінних високоенергетичних компонентів - перхлората амонію $i$ нітрамінів. Для вилучення нітрамінів з полімерної крихти твердого ракетного палива, з якої попередньо видалений перхлорат амонію, можливо застосовувати органічний розчинник метилсульфоксид (ДМСО). 3 одержаної полімерної крихти нітраміни вилучають ДМСО з подальшим відділенням екстракту від рафінованої полімерної крихти і висадженням нітрамінів введенням в розчин екстракту води (компонента, що не розчиняє нітраміни). Метою роботи є встановлення закономірностей процесу екстракції та визначення параметрів вилучення нітрамінів з продуктів утилізації твердого ракетного палива (полімерної крихти) за допомогою ДМСО. Встановлено залежності впливу температури, частоти обертання механічної мішалки, тривалості процесу на ступінь вилучення нітрамінів з полімерної крихти диметилсульфоксидом. Отримано кінетичні константи і кінетичне рівняння, що описуе процес вилучення нітрамінів з полімерної крихти із застосуванням ДМСО. У відпрацьованому водному розчині ДМСО присутній побічний продукт - сильний окислювач - перхлорат амонію, що небажано в процесі нагрівання і регенерації ДМСО. 3 відпрацьованого водного розчину ДМСО перхлорат амонію видаляється шляхом переведення його у малорозчинну сіль $\mathrm{KClO}_{4}$, яку можсливо застосовувати як окислювач і промислових вибухових речовинах.

Ключові слова: тверде ракетне паливо, екстракція, циклотетраметілентетранітрамін, перхлорат амонію, диметилсульфоксид. 


\section{EXTRACTION OF HIGH-ENERGY COMPONENTS FROM PRODUCTS OF RECOVERY OF SOLID PROPELLANT USING DIMETHYL SULFOXIDE}

M.M. Cheltonov ${ }^{a,}$, S.A. Oparin ${ }^{b}$, A.S. Matrosov ${ }^{b}$, A.L. Kirichenko ${ }^{a}$

a Pavlograd Chemical Plant, Pavlograd, Ukraine b Ukrainian State University of Chemical Technology, Dnipro, Ukraine

* e-mail: dizel2008@meta.ua

The recycling of solid propellant from loaded rocket motor cases of intercontinental ballistic missiles SS-24 results in the formation of polymer crumb that is used as an energetic additive to emulsion explosives. The polymer crumb contains a binder, an oxidizer (ammonium perchlorate), energetic additives (nitramine, in particular cyclotetramethylenetetranitramine, and aluminium) and some additives. One of the most efficient techniques for utilization of polymer crumb consists in extraction of valuable high-energy components such as ammonium perchlorate and nitramine. To extract nitramine from solid propellant crumb, from which ammonium perchlorate has been previously removed, an organic solvent, dimethyl sulphoxide (DMSO), can be used. Nitramine is to be extracted from the obtained solid propellant polymer crumb by using DMSO. Then the extract is separated from the refined polymer crumb and nitramine is precipitated by the addition of water (a diluent that does not dissolve nitramine) to the extract solution. The purpose of this work was to establish the characteristics of the extraction process and determine the parameters of the extraction of nitramine from the products of solid propellant recycling (polymer crumb) with the use of DMSO. The effects of temperature, mechanical agitator rotation frequency and process duration on the degree of the extraction of nitramine from solid propellant polymer crumb by dimethyl sulfoxide were determined. The kinetic constants and the kinetic equation that describes the extraction of nitramine from solid propellant polymer crumb using DMSO were obtained. Ammonium perchlorate is present as a byproduct in the spent DMSO aqueous solution. Ammonium perchlorate is a strong oxidizing agent and its presence is undesirable in the process of heating and regeneration of DMSO. Ammonium perchlorate can be removed from the spent DMSO aqueous solution by converting it into poorly soluble salt $\left(\mathrm{KClO}_{4}\right)$, which can be used as an oxidizing agent and in industrial explosives.

Keywords: solid propellant; extraction; cyclotetramethylenetetranitramine; ammonium perchlorate; dimethyl sulphoxide.

\section{REFERENCES}

1. Kim K.J., Kim H.S., Sim J.S. Solubilities of octahydro1,3,5,7-tetranitro-1,3,5,7-tetrazocine in $\gamma$-butyrolactone + water, dimethylsulfoxide + water, and $\mathrm{N}$-methyl pyrrolidone + water. Journal of Chemical \& Engineering Data, 2013, vol. 58, pp. 24102413.

2. Dyachok V. Extraction process of intracellular substance. Chemistry \& Chemical Technology, 2010, vol. 4, pp. 163-166.

3. Dyachok V., Maljovanyj M., Ilkiv I. Some kinetic regularities of intracellular substance extracting. Chemistry \& Chemical Technology, 2011, vol. 5, pp. 469-472.

4. Dyachok V., Ilkiv I. On the mechanism of extraction from solid bodies cellular structure. Chemistry \& Chemical Technology, 2013, vol. 7, pp. 23-27.

5. Zakusilo V.R., Romanchenko A.M., Zakusilo R.V. Vliyanie katalizatorov na termicheskoe razlozhenie perkhlorata kaliya i vzryvchatye kharakteristiki sostavov na ego osnove [Influence of catalysts on the thermal decomposition of potassium perchlorate and explosive characteristics of composition based on it]. Visnyk Kremenchuts'kogo Derzhavnogo Universytetu imeni Mykhaila Ostrograds'kogo, 2013, no. 5(82), pp. 103-107. (in Russian). 